\title{
Structural Soundness of Carpio Hall and Federizo Hall: Inputs for planning and renovation of buildings in Bulacan State University
}

\author{
Charlene May N. Rivera* \\ Architecture Department, College of Architecture and Fine Arts, Bulacan State University, City of Malolos, Bulacan, \\ Philippines, 3000.
}

Global Journal of Engineering and Technology Advances, 2021, 08(03), 087-100

Publication history: Received on 14 August 2021; revised on 16 September 2021; accepted on 18 September 2021

Article DOI: https://doi.org/10.30574/gjeta.2021.8.3.0131

\begin{abstract}
The study focused on determining the structural soundness of Carpio Hall and Federizo Hall in Bulacan State UniversityMain Campus. The parameters used were the age of the building, material used, existing condition, and the compressive strength of the beams, columns, and slabs of the two buildings. The processes and tests that involve include visual inspection, non - destructive testing, hypothesis testing, and interview. The performance of non-destructive testing, particularly Hammer Rebound Test is to determine the compressive strength of each structural member followed by hypothesis testing to establish the significance of the compressive strength in each floor level.

Based on the results, a Structural Audit Plan for Carpio Hall and Federizo Hall was proposed. It may be used as a basis in allocating a budget for the repair, retrofitting, and renovation. Some of the structural members of Carpio Hall and Federizo Hall already manifest signs of deterioration due to its age and improper maintenance. It is necessary to conduct visual/tapping observation to monitor the changes in the building and easily determine what members need repair. The use of non - destructive equipment like hammer rebound test is efficient in providing immediate test result and advisable to be of use as it will not contribute in the further damage of members. It is advisable to conduct a structural audit of buildings regularly or as needed to avoid more damage. Structural Audit Management Plan is also necessary as it will help in providing preventive maintenance plan to increase the service life of a building.
\end{abstract}

Keywords: Structural soundness; Compressive strength; Non-destructive test; Visual inspection; Retrofitting

\section{Introduction}

Structure is a network of interconnected members such as beams, columns and slab to safely carry loads down to the underground earth [1]. Structural members are the principal load-bearing component of the building and each has its own structural functions and properties that need to be considered. Slabs transfer the loads that they carry to the beams; beams are structural members that convey the load from the slab to its supports; and columns, on the other hand, are compression members that transfer their load to the structural members below. Structural elements are designed and planned by structural engineers and/or by a registered civil engineer.

Structural members may be designed to use materials like reinforced concrete, timbers and structural steels. Reinforced concrete is concrete in which reinforcements have been incorporated to strengthen a brittle material, which is concrete. They can be also made from timbers, which are the oldest structural materials. The timber properties are non-linear and very variable, depending on the quality, treatment of wood, and type of wood supplied. On the other hand, steel is used exceptionally widely in all kinds of structures because of its high strength-to-weight ratio, relatively low cost, and construction speed. Steel is a construction material that is weak in fires and is protected in most structures.

\footnotetext{
${ }^{*}$ Corresponding author: Charlene May N. Rivera

Architecture Department, College of Architecture and Fine Arts, Bulacan State University, City of Malolos, Bulacan, Philippines, 3000. 
Compressive strength is one of the essential parameters used in the design of reinforced concrete structures. However, concrete does not provide the much needed tensile strength. Perhaps, this is the fundamental idea of building reinforced concrete, where steel reinforcement provides the much-needed tensile strength of the section. Compressive strength has the same degree of importance in the evaluation of existing structures. Ductility and stiffness are other structural characteristics that can be defined as functions of compressive strength.

The "structural soundness" of a building is the building's preparedness to withstand the loads it is designed for or it is exposed to. A structurally sound building is a building that has no structural issues. On the other hand, a building that is not structurally sound is at risk of suffering from structural damages, and in the worst case collapse. A building may not be structurally sound because an earthquake has damaged it for example, or some flaws or errors in its design.

The strength of structures reduces due to its usage, input of poor-quality construction materials, environmental conditions, improper practice, or poor workmanship. Also, several factors such as plastic deformation, interaction with the environment, initial design, construction flaws and natural disasters develop distress in the structure, resulting in the development of cracks, corrosion in reinforcement, leakage and seepage. The final soundness of a building can vary due to numerous reasons, and only proper precautions at the initial stage and good maintenance in the later lifespan of the structure can result in a technically sound building [2].

According to the latest report published by the World Risk Report 2018 of the United Nations, the Philippines was considered the third most vulnerable country in the world. The report ranked 171 countries, and the Philippines ranked behind Vanuatu and Tonga. This is the country's third year on the third place after moving down from second place in the year 2015. The Philippines lies along the Pacific Ring of Fire's western segment, where the most active part of the earth is found and considered earthquake generators. An example of this is the Bohol earthquake in 2013 and the Northern Philippine earthquake in 1990, which were considered as one of the most devastating disasters in Philippine history.

School buildings, being one of the most important facilities in the community, are of course susceptible to disasters, be it man-made or natural disasters. Catering more than 27.7 million students for public and private schools, education in the Philippines is a massive undertaking (UNICEF, 2012) It is essential that school buildings are safe and prepared for they are widely used as evacuation centers during disasters. However, sometimes due to different circumstances and conditions, some school buildings are unable to withstand hazards.

Bulacan State University is a 115-year-old state - operated institution in Central Luzon. It progressed from a secondary school into one of biggest educational institutions in Region III. The university is catering more than 1, 500 personnel and more than 35, 000 students. Two of the university's oldest buildings are Carpio Hall and Federizo Hall which were constructed in year 1979 and 1981 respectively. Many damages may arise due to cracks, seepage, concrete spalling, and corroded reinforcing bars. These defects need to be assessed to apply proper repair and retrofitting procedures to increase each building's lifespan. If not properly assessed and repaired, these kinds of defects in the building may cause waste of resources, dangerous working and learning environment, or in worst case physical injuries and psychotraumatics insults to the stakeholders of the University. Carpio Hall houses students from Laboratory High school, College of Education and Graduate School, while Federizo Hall accommodates College of Science, College of Arts and Letters and College of Architecture and Fine Arts and Graduate School students. This research aimed to evaluate the structural soundness of Carpio Hall and Federizo Hall inside the main campus to provide inputs to the university administration in deciding and allocating funds for possible retrofitting of structures and its preparedness and reduction of disaster risks.

\section{Material and methods}

\subsection{Methods and techniques of the study}

This study considered mixed-methods type of research. The quantitative part consists of the test results analysis. To support the test results, interviews and visual inspection were conducted. The main objective is to evaluate and investigate the structural soundness of Carpio Hall and Federizo Hall. The preliminary investigation covered the existing condition of each structural member. This study also investigated through on - site testing the structural soundness of Carpio Hall and Federizo Hall without incurring damages to the structures. The investigation was conducted by using visual observation/inspection to determine the age, existing condition and materials used and the structural soundness of the structures was determined using Hammer Rebound Testing/Schmidt Hammer Testing. Hammer rebound test provided a convenient and rapid indication of the compressive strength of hardened concrete without sacrificing the strength of the structure. 


\subsection{Research Instruments}

This study relied on checklist as one source of data gathering. The researcher adopted and modified an instrument based on Shah's detailed inspection guide of buildings [3]. The checklist was used to reveal the detailed structural member's existing condition like cracks, rusting, leakages and others. It was also designed to seek information about the repairs and renovation that the building has undergone to this date. To substantiate the study, building plans and other related construction plans for renovations were also perused for the purpose of the study.

\subsection{Data Gathering Procedure}

As part of preliminary investigation, visual inspection was conducted. Buildings were thoroughly inspected from every corner noting cracks and seepage. During the visual inspection, some structural members were subjected to hammer tapping to know whether there is spalling of concrete or whether it is hollow or dense. Visual inspection and tapping observation were used to determine the critical areas.

A non - destructive testing, Hammer Rebound Test followed after highlighting the critical area through the visual inspection. The use of rebound - hammer test was done to determine the compressive strength of the concrete, uniformity of concrete and quality of concrete. In the procedure of rebound hammer test, the plunger of rebound hammer was pressed on the surface of concrete for the spring with a constant energy to hit the concrete surface. At the same time, a spring-controlled mass rebounded back as. This extent of rebound on a graduated scale was measured for the surface hardness. This value was then designated as Rebound Number or a Rebound Index. Rebound hammer test method can be used to differentiate the acceptable and questionable parts of the structure or to compare two different structures based on strength.

\subsection{Data Processing and Statistical Tools used in the study}

The data gathered from the research instruments will be consolidated accordingly and tabulated. The tabulated data will be presented according to specific problems of the study. These will be treated with the use of weighted mean. The quality of concrete will be evaluated using Average Rebound Number. The remarks of analysis report will be given in description and color coding so as to simplify it for Non-Technical person.

The researcher used color to show the result of the study. Structural members of Carpio Hall and Federizo Hall was marked using the given color coding depending on the analyzed result of the visual inspection and hammer rebound testing. Major distress member was be marked red, considerable distress but still repairable member was marked orange, moderate distress and still repairable members was marked yellow and structurally sound compressive strength was marked green.

Statistical tools were employed to describe the structural soundness of the structural members. The researcher used central tendency to estimate of the "center" of a distribution of values from the result of the rebound hammer testing. Central tendency was computed using "mean or average method". To compute the mean, just add up all the values and divide by the number of values or Mean $=\frac{\sum x}{n}$ where $\mathrm{x}$ is the values recorded from the hammer rebound scale and $\mathrm{n}$ is the number of testing performed per structural members.

The researcher performed a One Sample T- Test on the mean computed obtained from the non - destructive test result of Carpio Hall and Federizo Hall. The one-sample t-test compares the mean of a single sample to a predetermined value to determine if the sample mean is significantly greater or less than that value. In this study, the researcher used the standardized plan for public school building of Department of Public Works and Highway which states that compressive strength of school building is $28 \mathrm{Mpa}$.

\section{Result and Discussion}

Members to be subjected for non - destructive testing were based on the result of visual inspection. However, for members recorded with damages that are adjacent with each other, the researcher only chose samples to be considered to cater other beams, slabs and columns. These members from other areas of the building were also subjected to non destructive testing to test overall soundness of the two buildings.

Table 1 shows the descriptive measures in terms of age, materials, existing condition and compressive strength of beams, columns and slabs of Carpio Hall. The table shows that Carpio Hall experienced extension and already exceeded the number of years wherein both the contractor and designers were no longer liable to the building. Visual inspection showed that Carpio Hall now exhibits various signs of damage like cracks, concrete spalling, leaks and exposed 
reinforcing steel bars. Portion of slab in second floor was found to be suffering from major scaling and the non destructive test result in this portion gave a fair concrete quality. There is also beam recorded with cracks and the non - destructive test result gave a good quality of concrete. Meanwhile, other member recorded with damage gave a very good hard layer quality of concrete.

Table 1 Visual Inspection and Non - Destructive Test Result for Carpio Hall

\begin{tabular}{|c|c|c|c|c|c|c|c|c|}
\hline SN & $\begin{array}{l}\text { Structural } \\
\text { Member }\end{array}$ & Location & Age & Material & $\begin{array}{l}\text { Existing } \\
\text { Condition }\end{array}$ & $\begin{array}{l}\text { Rebound } \\
\text { Number }\end{array}$ & $\begin{array}{l}\text { Compressive } \\
\text { Strength }\end{array}$ & $\begin{array}{l}\text { Quality of } \\
\text { Concrete }\end{array}$ \\
\hline 1 & Beam & $\begin{array}{lc}\text { 3rd } & \text { Floor } \\
\text { Grid } & \text { BC, } \\
11-13 & \end{array}$ & $\begin{array}{l}41 \\
\text { years }\end{array}$ & Concrete & Cracks & 37.50 & 17.00 & $\begin{array}{l}\text { Good } \\
\text { Layer }\end{array}$ \\
\hline 2 & Slab & $\begin{array}{l}\text { 2nd Floor } \\
\text { BC, 20-21 }\end{array}$ & $\begin{array}{l}41 \\
\text { years }\end{array}$ & Concrete & Major Scaling & 24.50 & 9.00 & Fair \\
\hline 3 & Slab & $\begin{array}{l}\text { 2nd Floor } \\
\text { Grid DE, 6- } \\
7\end{array}$ & $\begin{array}{l}27 \\
\text { years }\end{array}$ & Concrete & $\begin{array}{l}\text { Spalling of } \\
\text { Concrete }\end{array}$ & 63.00 & 57.00 & $\begin{array}{l}\text { Very Good } \\
\text { Hard } \\
\text { Layer }\end{array}$ \\
\hline 4 & Slab & $\begin{array}{l}\text { 2nd Floor } \\
\text { Grid C-D, } \\
20-21\end{array}$ & $\begin{array}{l}41 \\
\text { years }\end{array}$ & Concrete & $\begin{array}{l}\text { Hairline } \\
\text { Cracks }\end{array}$ & 60.10 & 49.50 & $\begin{array}{l}\text { Very Good } \\
\text { Hard } \\
\text { Layer }\end{array}$ \\
\hline 5 & Slab & $\begin{array}{l}\text { 2nd Floor } \\
\text { Grid DE, } \\
20-21\end{array}$ & $\begin{array}{l}27 \\
\text { years }\end{array}$ & Concrete & $\begin{array}{l}\text { Hairline } \\
\text { Cracks }\end{array}$ & 60.40 & 50.50 & $\begin{array}{l}\text { Very Good } \\
\text { Hard } \\
\text { Layer }\end{array}$ \\
\hline 6 & Slab & $\begin{array}{l}\text { 3rd Floor } \\
\text { Grid D-E, } \\
14-15\end{array}$ & $\begin{array}{l}27 \\
\text { years }\end{array}$ & Concrete & $\begin{array}{l}\text { Leakages, } \\
\text { Concrete } \\
\text { Spalling }\end{array}$ & 57.00 & 42.50 & $\begin{array}{l}\text { Very Good } \\
\text { Hard } \\
\text { Layer }\end{array}$ \\
\hline 7 & Slab & $\begin{array}{l}\text { 3rd Floor } \\
\text { Grid D-E, } \\
13-14\end{array}$ & $\begin{array}{l}27 \\
\text { years }\end{array}$ & Concrete & $\begin{array}{l}\text { Exposed } \\
\text { Bars, } \\
\text { Concrete } \\
\text { Spalling }\end{array}$ & 50.50 & 31.50 & $\begin{array}{l}\text { Very Good } \\
\text { Hard } \\
\text { Layer }\end{array}$ \\
\hline 8 & Beam & $\begin{array}{l}\text { 3rd Floor } \\
\text { Grid D-E, } 7- \\
10\end{array}$ & $\begin{array}{l}27 \\
\text { years }\end{array}$ & Concrete & $\begin{array}{l}\text { Exposed } \\
\text { Bars, } \\
\text { Concrete } \\
\text { Spalling and } \\
\text { leakages }\end{array}$ & 46.00 & 25.00 & $\begin{array}{l}\text { Very Good } \\
\text { Hard } \\
\text { Layer }\end{array}$ \\
\hline 9 & Slab & $\begin{array}{l}\text { 3rd Floor } \\
\text { Grid D-E, 9- } \\
10\end{array}$ & $\begin{array}{l}27 \\
\text { years }\end{array}$ & Concrete & $\begin{array}{l}\text { Exposed } \\
\text { Bars, } \\
\text { Concrete } \\
\text { Spalling and } \\
\text { leakages }\end{array}$ & 45.90 & 25.00 & $\begin{array}{l}\text { Very Good } \\
\text { Hard } \\
\text { Layer }\end{array}$ \\
\hline
\end{tabular}

Table 2 on the other hand shows the descriptive measures in terms of age, materials, existing condition and compressive strength of beams, columns and slabs of Federizo Hall. The table shows that Federizo Hall also already exceeds the number of years wherein both the contractor and designers is no longer liable to the building. Visual inspection shows that Federizo Hall now exhibits various signs of damage like cracks, concrete spalling, leaks and exposed reinforcing steel bars. Non - destructive test results on the members recorded with damages gave a very good hard layer quality of concrete. 
Table 2 Visual Inspection and Non - Destructive Test Result for Federizo Hall

\begin{tabular}{|c|c|c|c|c|c|c|c|c|}
\hline SN & $\begin{array}{l}\text { Structural } \\
\text { Member }\end{array}$ & Location & Age & Material & $\begin{array}{l}\text { Existing } \\
\text { Condition }\end{array}$ & $\begin{array}{l}\text { Rebound } \\
\text { Number }\end{array}$ & $\begin{array}{l}\text { Compressive } \\
\text { Strength }\end{array}$ & $\begin{array}{l}\text { Quality of } \\
\text { Concrete }\end{array}$ \\
\hline 1 & Beam & $\begin{array}{l}\text { 2nd Floor } \\
\text { Grid P,2-3 }\end{array}$ & $\begin{array}{l}39 \\
\text { years }\end{array}$ & Concrete & $\begin{array}{l}\text { Spalling of } \\
\text { Concrete }\end{array}$ & 64.40 & 61.00 & $\begin{array}{l}\text { Very Good } \\
\text { Hard Layer }\end{array}$ \\
\hline 2 & Slab & $\begin{array}{l}\text { 2nd Floor } \\
\text { Grid R-S, 1-2 }\end{array}$ & $\begin{array}{l}39 \\
\text { years }\end{array}$ & Concrete & $\begin{array}{l}\text { Spalling of } \\
\text { Concrete }\end{array}$ & 54.40 & 37.50 & $\begin{array}{l}\text { Very Good } \\
\text { Hard Layer }\end{array}$ \\
\hline 3 & Slab & $\begin{array}{ll}\text { 2nd } & \text { Floor } \\
\text { Grid } & \text { V-W, } \\
10-11 & \end{array}$ & $\begin{array}{l}39 \\
\text { years }\end{array}$ & Concrete & $\begin{array}{l}\text { Exposed } \\
\text { Rebar }\end{array}$ & 60.30 & 50.00 & $\begin{array}{l}\text { Very Good } \\
\text { Hard Layer }\end{array}$ \\
\hline 4 & $\begin{array}{l}\text { Slab } \\
\text { (Canopy) }\end{array}$ & $\begin{array}{l}\text { 2nd Floor } \\
\text { Grid T-W, 7- } \\
8\end{array}$ & $\begin{array}{l}39 \\
\text { years }\end{array}$ & Concrete & $\begin{array}{l}\text { Spalling of } \\
\text { Concrete }\end{array}$ & 67.30 & 70.00 & $\begin{array}{l}\text { Very Good } \\
\text { Hard Layer }\end{array}$ \\
\hline 5 & Slab & $\begin{array}{l}\text { 2nd Floor } \\
\text { Grid V-W, } 4- \\
5\end{array}$ & $\begin{array}{l}39 \\
\text { years }\end{array}$ & Concrete & $\begin{array}{l}\text { Spalling of } \\
\text { Concrete } \\
\text { Exposed } \\
\text { Rebar }\end{array}$ & 50.90 & 32.00 & $\begin{array}{l}\text { Very Good } \\
\text { Hard Layer }\end{array}$ \\
\hline 6 & Slab & $\begin{array}{l}\text { 2nd Floor } \\
\text { Grid W-Y, 6- } \\
7\end{array}$ & $\begin{array}{l}39 \\
\text { years }\end{array}$ & Concrete & $\begin{array}{l}\text { Spalling of } \\
\text { Concrete } \\
\text { Exposed } \\
\text { Rebar }\end{array}$ & 61.40 & 53.00 & $\begin{array}{l}\text { Very Good } \\
\text { Hard Layer }\end{array}$ \\
\hline 7 & Beam & $\begin{array}{l}\text { 2nd Floor } \\
\text { Grid V-W, } 9\end{array}$ & $\begin{array}{l}39 \\
\text { years }\end{array}$ & Concrete & $\begin{array}{l}\text { Exposed } \\
\text { Rebar }\end{array}$ & 69.90 & 79.50 & $\begin{array}{l}\text { Very Good } \\
\text { Hard Layer }\end{array}$ \\
\hline 8 & Beam & $\begin{array}{l}\text { 2nd Floor } \\
\text { Beam Grid } \\
W, 13-14\end{array}$ & $\begin{array}{l}39 \\
\text { years }\end{array}$ & Concrete & $\begin{array}{l}\text { Spalling of } \\
\text { Concrete }\end{array}$ & 66.40 & 67.00 & $\begin{array}{l}\text { Very Good } \\
\text { Hard Layer }\end{array}$ \\
\hline 9 & Beam & $\begin{array}{l}\text { 2nd Floor } \\
\text { TV-7 }\end{array}$ & $\begin{array}{l}39 \\
\text { years }\end{array}$ & Concrete & $\begin{array}{l}\text { Spalling of } \\
\text { Concrete }\end{array}$ & 68.40 & 74.00 & $\begin{array}{l}\text { Very Good } \\
\text { Hard Layer }\end{array}$ \\
\hline 10 & Beam & $\begin{array}{l}\text { 2nd Floor } \\
\text { TV-8 }\end{array}$ & $\begin{array}{l}39 \\
\text { years }\end{array}$ & Concrete & $\begin{array}{l}\text { Spalling of } \\
\text { Concrete }\end{array}$ & 49.90 & 30.50 & $\begin{array}{l}\text { Very Good } \\
\text { Hard Layer }\end{array}$ \\
\hline 11 & Slab & $\begin{array}{l}\text { Roof deck } \\
\text { Grid 3-4, E-F }\end{array}$ & $\begin{array}{l}39 \\
\text { years }\end{array}$ & Concrete & $\begin{array}{l}\text { Spalling of } \\
\text { Concrete } \\
\text { Exposed } \\
\text { Rebar }\end{array}$ & 46.10 & 25.50 & $\begin{array}{l}\text { Very Good } \\
\text { Hard Layer }\end{array}$ \\
\hline 12 & Roof beam & Grid 4 E-F & $\begin{array}{l}39 \\
\text { years }\end{array}$ & Concrete & $\begin{array}{l}\text { Spalling of } \\
\text { Concrete } \\
\text { Exposed } \\
\text { Rebar }\end{array}$ & 41.40 & 20.90 & $\begin{array}{l}\text { Very Good } \\
\text { Hard Layer }\end{array}$ \\
\hline 13 & Slab & $\begin{array}{l}\text { Roof Deck } \\
\text { Grid ST,3-4 }\end{array}$ & $\begin{array}{l}39 \\
\text { years }\end{array}$ & Concrete & $\begin{array}{l}\text { Spalling of } \\
\text { Concrete }\end{array}$ & 63.10 & 57.50 & $\begin{array}{l}\text { Very Good } \\
\text { Hard Layer }\end{array}$ \\
\hline 14 & Slab & $\begin{array}{l}\text { Roof Deck } \\
\text { Grid UW,3-4 }\end{array}$ & $\begin{array}{l}39 \\
\text { years }\end{array}$ & Concrete & $\begin{array}{l}\text { Spalling of } \\
\text { Concrete }\end{array}$ & 59.70 & 48.50 & $\begin{array}{l}\text { Very Good } \\
\text { Hard Layer }\end{array}$ \\
\hline
\end{tabular}

Both building already reached the number of years wherein both the contractor and designer is no longer liable to the building. Upon inspection, both buildings already manifest defects that were caused by several problems. ACI 364.1 states that to completely solve the problem there is a need to determine the root cause of the problem before addressing it [4]. 


\subsection{Hypothesis Testing}

The researcher performed One Sample T Test on the compressive strength obtained from the non - destructive test result. The hypothesis set in the study was that there is no difference that exists between the rebound hammer compressive strength values and the standard value of $28 \mathrm{MPa}$ (null hypothesis). $28 \mathrm{MPa}$ compressive strength is from the building plan of Department of Public Works and Highway standardized for public school buildings. The following table is the result of One Sample T-Test performed for Carpio Hall and Federizo Hall respectively.

Table 3 shows the compressive strength mean per building level obtained from the non - destructive test result, mean difference, $t$-value, degree of freedom, $p$-value and the remarks given by the researcher. The table gives two $p$-value that is greater than 0.05 which mean there is no difference between these values against the standard values. On the other hand, the rest gives a p-value lower than 0.05 which mean the observe value is significantly different from the standard value. The null hypothesis $(\mu=28)$ is not rejected at $5 \%$ level for the slab ( $2^{\text {nd }}$ floor $)$ and slab ( $3^{\text {rd }}$ floor $)$. The compressive strength is not significantly different from $28 \mathrm{MPa}$ which given a remarks of "meet the standard".

Table 3 Results of One sample test of Means of Compressive Strength of Carpio Hall

\begin{tabular}{|l|l|l|l|l|l|l|}
\hline \multicolumn{1}{|c|}{ Structure } & Mean (SD) & $\begin{array}{c}\text { Mean } \\
\text { difference }\end{array}$ & t-value & df & p-value & Remarks \\
\hline Column (1st floor) & $56.73(9.35)$ & 28.73 & 11.07 & 12 & 0 & Above the standard \\
\hline Beam(2nd floor) & $45.21(13.63)$ & 17.21 & 4.726 & 13 & 0 & Above the standard \\
\hline Column (2nd floor) & $51.14(15.11)$ & 23.14 & 5.731 & 13 & 0 & Above the standard \\
\hline Slab (2nd floor) & $41.83(16.99)$ & 13.833 & 1.995 & 5 & 0.103 & Below the standard \\
\hline Beam (3rd floor) & $39.36(15.96)$ & 11.36 & 2.66 & 13 & 0.02 & Above the standard \\
\hline Column (3rd floor) & $55.09(10.81)$ & 27.09 & 10.023 & 15 & 0 & Above the standard \\
\hline Slab (3rd floor) & $36.8(10.86)$ & 8.8 & 2.563 & 9 & 0.031 & Above the standard \\
\hline & & & & & & \\
\hline
\end{tabular}

Table 4 shows the compressive strength mean per building level obtained from the non - destructive test result, mean difference, $t$-value, degree of freedom, $p$-value and the remarks given by the researcher. The table gives two $p$-value that is greater than 0.05 which mean there is no difference between these values against the standard values. On the other hand, the rest gives a p-value lower than 0.05 which mean the observe value is significantly different from the standard 
value. The null hypothesis $(\mu=28)$ is not rejected at $5 \%$ level for the beam (roof deck level) and slab (roof deck level). The compressive strength is not significantly different from $28 \mathrm{MPa}$ which given a remarks of "meet the standard".

Table 4 Results of One sample test of Means of Compressive Strength of Federizo Hall

\begin{tabular}{|c|c|c|c|c|c|c|}
\hline Structure & Mean (SD) & Mean difference & t-value & df & p-value & Remarks \\
\hline Column (1st floor) & $64.83(14.65)$ & 36.82 & 12.819 & 25 & 0 & Above the standard \\
\hline Beam(2nd floor) & $57.95(20.34)$ & 29.95 & 8.957 & 36 & 0 & Above the standard \\
\hline Column (2nd floor) & $44.71(15.78)$ & 16.71 & 5.188 & 23 & 0 & Above the standard \\
\hline Beam(3rd floor) & $49.35(11.96)$ & 21.35 & 5.645 & 9 & 0 & Above the standard \\
\hline Slab (2nd floor) & $43.08(13.35)$ & 15.07 & 5.761 & 25 & 0 & Above the standard \\
\hline Column(3rd floor) & $37.96(16.75)$ & 9.96 & 3.091 & 26 & 0.005 & Above the standard \\
\hline Beam (Roof Deck Level) & $30.18(13.04)$ & 2.17 & 0.688 & 16 & 0.501 & Below the standard \\
\hline Slab(Roof Deck Level) & $45.88(14.08)$ & 17.87 & 2.539 & 3 & 0.085 & Below the standard \\
\hline
\end{tabular}

\subsection{Structural Condition of Carpio Hall and Federizo Hall}

This part of the chapter presents the result of the interview done with expert individuals in the field of civil engineering and construction management that can prove and support the data already presented on the descriptive part of the study. The interviewed professionals are the former and current head of the office in charge in the design and implementation of the physical project of the university.

Most of the buildings were prepared and designed by the former head of the office some were from Department of Public Work and Highways. Former monitoring head and an expert in civil engineering was in charged in the construction of Federizo Hall way back 1980. The building was completed and occupied by faculty, employees and student by year 1983. Original plan for Carpio Hall was already completed that time and it was in 1987 when it was renovated with an additional bay and used as corridor.

Old buildings in the university already experienced earthquake with low, medium, and high intensities over the years. The earthquake in 1990 had the highest intensity so far, that time Carpio Hall and Federizo Hall were at the age wherein the designer and contractors were no longer liable to the structure. Professionals requested building officials and Department of Public Work and Highways to conduct inspection (visual), and so far the worst observation reported was cracks in roof slab of Federizo Hall and exposed reinforcing bars due to concrete spalling with no reported damages in other structural members. April 2019 was the latest earthquake experienced by the buildings. Professionals from the 
university together with the engineers from Department of Public Works and Highways and City Engineering conducted visual inspections and there were no major damages aside from spalling of concrete, hairline cracks and exposed reinforcing steel bars. As of to date, there was no record of other testing performed in these buildings be it destructive and non - destructive testing.

Former heads concerning the physical projects of the university appreciate this study and recommended to conduct structural audit of all buildings in the university. Although seemed to be sound, repairs and retrofitting is necessary to increase the service life of buildings. It is also necessary to make it habitable and safe but there is a need to prepare a plan to make it timely, responsive and identify the appropriate preventive maintenance tool.

Table 13 shows the method of repair based on the result of Visual Inspection and Non - destructive Test, a Structural Audit Plan for Carpio Hall .The recommendation was based on the American Concrete Institute 224.1R Methods of Cracks Repair [5].

Table 5 Structural Audit Plan for Carpio Hall

\begin{tabular}{|c|c|c|c|c|c|c|}
\hline SN & $\begin{array}{l}\text { Structural } \\
\text { Member }\end{array}$ & Location & Age & Material & $\begin{array}{l}\text { Existing } \\
\text { Condition }\end{array}$ & Method of Repair \\
\hline 1 & Beam & $\begin{array}{l}\text { 3rd Floor Grid } \\
\text { BC, 11-13 }\end{array}$ & 41 years & Concrete & Cracks & Epoxy Injection \\
\hline 2 & Slab & $\begin{array}{l}\text { 2nd Floor BC, } \\
20-21\end{array}$ & 41 years & Concrete & Major Scaling & $\begin{array}{ll}\text { Retrofitting } & \text { by } \\
\text { Additional } & \\
\text { Reinforcement } & \end{array}$ \\
\hline 3 & Slab & $\begin{array}{l}\text { 2nd Floor Grid } \\
\text { DE, 6-7 }\end{array}$ & 27 years & Concrete & $\begin{array}{l}\text { Spalling of } \\
\text { Concrete }\end{array}$ & $\begin{array}{l}\text { Application of Rust } \\
\text { Converter and Epoxy } \\
\text { Plastering }\end{array}$ \\
\hline 4 & Slab & $\begin{array}{l}\text { 2nd Floor Grid } \\
\text { C-D, 20-21 }\end{array}$ & 41 years & Concrete & Hairline Cracks & Epoxy Injection \\
\hline 5 & Slab & $\begin{array}{l}\text { 2nd Floor Grid } \\
\text { DE, } 20-21\end{array}$ & 27 years & Concrete & Hairline Cracks & Epoxy Injection \\
\hline 6 & Slab & $\begin{array}{l}\text { 3rd Floor Grid } \\
\text { D-E, 14-15 }\end{array}$ & 27 years & Concrete & $\begin{array}{l}\text { Leakages, } \\
\text { Concrete Spalling }\end{array}$ & $\begin{array}{l}\text { Installation of Floor } \\
\text { Drain, Waterproofing, } \\
\text { Epoxy Plastering and } \\
\text { Application of Rust } \\
\text { Converter }\end{array}$ \\
\hline 7 & Slab & $\begin{array}{l}\text { 3rd Floor Grid } \\
\text { D-E, 13-14 }\end{array}$ & 27 years & Concrete & $\begin{array}{l}\text { Exposed Bars, } \\
\text { Concrete Spalling }\end{array}$ & $\begin{array}{l}\text { Epoxy Plastering and } \\
\text { Application of Rust } \\
\text { Converter }\end{array}$ \\
\hline 8 & Beam & $\begin{array}{l}\text { 3rd Floor Grid } \\
\text { D-E, 7-10 }\end{array}$ & 27 years & Concrete & $\begin{array}{l}\text { Exposed Bars, } \\
\text { Concrete Spalling } \\
\text { and leakages }\end{array}$ & $\begin{array}{l}\text { Installation of Floor } \\
\text { Drain, Waterproofing, } \\
\text { Epoxy Plastering and } \\
\text { Application of Rust } \\
\text { Converter }\end{array}$ \\
\hline 9 & Slab & $\begin{array}{l}\text { 3rd Floor Grid } \\
\text { D-E, 9-10 }\end{array}$ & 27 years & Concrete & & $\begin{array}{l}\text { Installation of Floor } \\
\text { Drain, Waterproofing, } \\
\text { Epoxy Plastering and } \\
\text { Application of Rust } \\
\text { Converter }\end{array}$ \\
\hline
\end{tabular}

Figures shown below presents the location of tested members in Carpio Hall and its color remarks based on the Description and Color Coding of Structural Members (modified from Biraris et.al, 2017). 


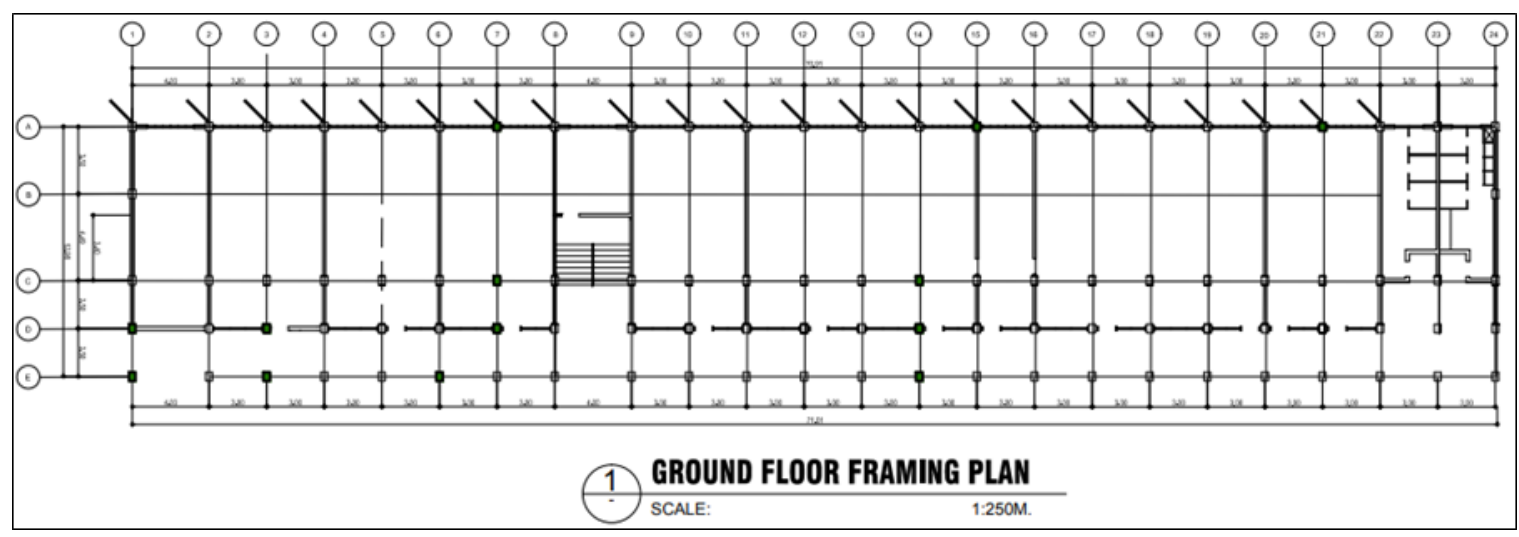

Figure 1 Color coded analysis report of Non - destructive test of Carpio Hall Ground Floor

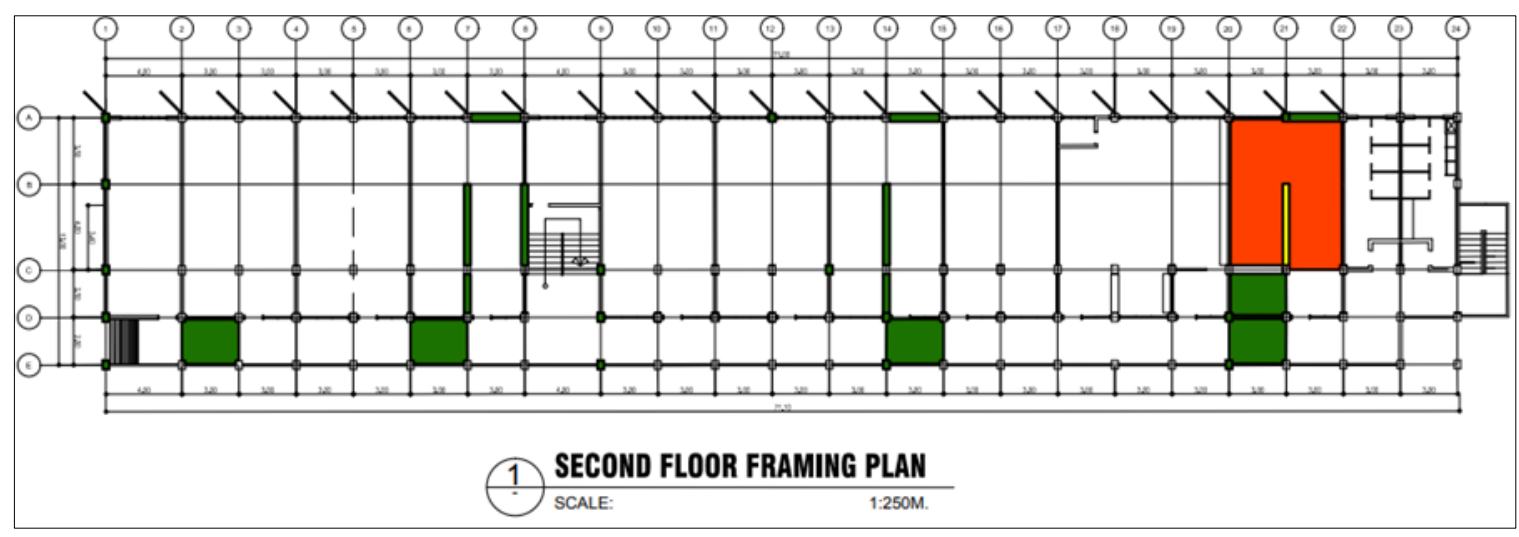

Figure 2 Color coded analysis report of Non - destructive test of Carpio Hall Second Floor

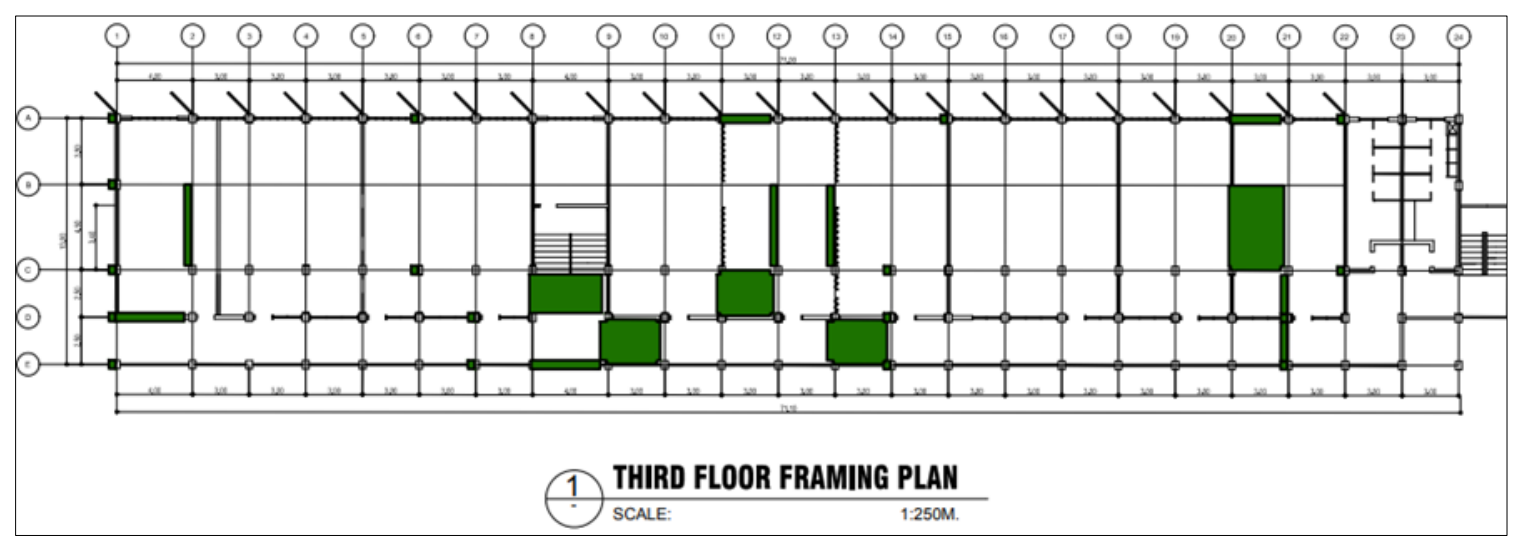

Figure 3 Color coded analysis report of Non - destructive test of Carpio Hall Third Floor 


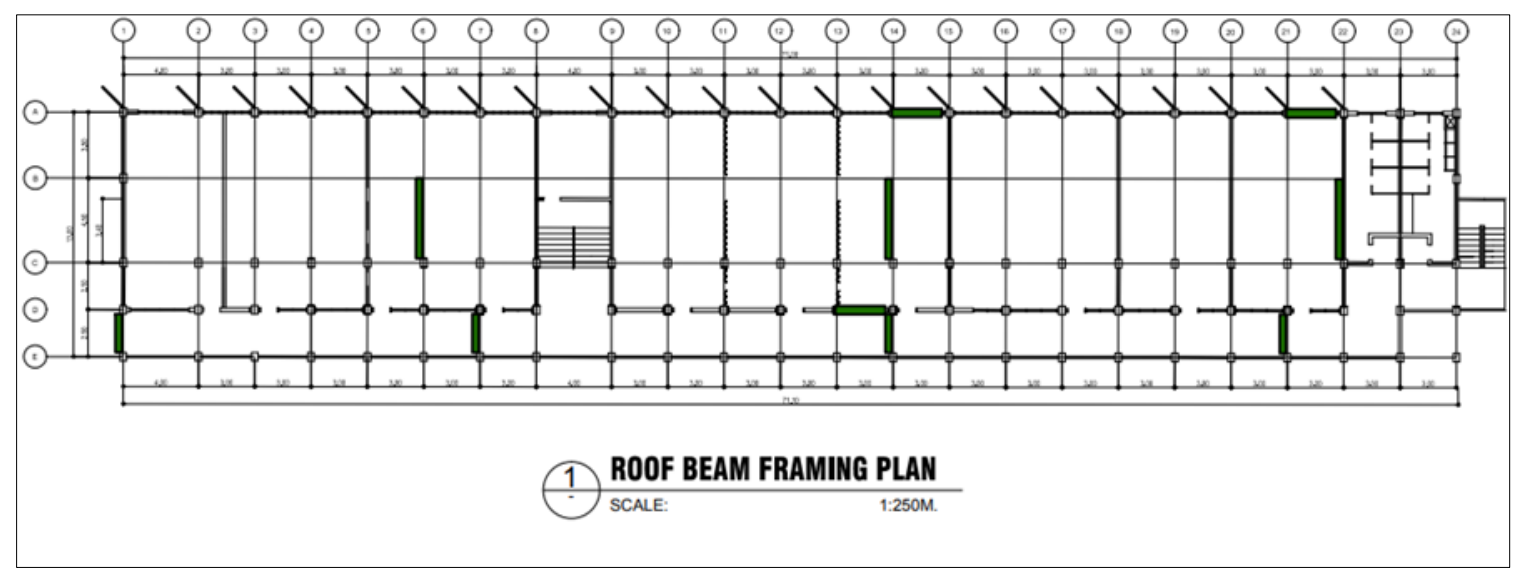

Figure 4 Color coded analysis report of Non - destructive test of Carpio Hall Roof Framing

Table 6 shows the method of repair based on the result of Visual Inspection and Non - destructive Test, a Structural Audit Plan for Federizo Hall .The recommendation was based on the American Concrete Institute 224.1R Methods of Cracks Repair.

Table 6 Structural Audit Plan for Federizo Hall

\begin{tabular}{|c|c|c|c|c|c|c|c|c|}
\hline SN & Structural & Location & Age & Material & Existing & Method of $\mathrm{P}$ & epair & \\
\hline 1 & Beam & $\begin{array}{l}\text { 2nd Floor } \\
\text { Grid P,2-3 }\end{array}$ & $\begin{array}{l}39 \\
\text { years }\end{array}$ & Concrete & $\begin{array}{l}\text { Spalling of } \\
\text { Concrete }\end{array}$ & $\begin{array}{l}\text { Application } \\
\text { Converter } \\
\text { Plastering }\end{array}$ & $\begin{array}{l}\text { of } \\
\text { and }\end{array}$ & $\begin{array}{r}\text { Rust } \\
\text { Epoxy }\end{array}$ \\
\hline 2 & Slab & $\begin{array}{l}\text { 2nd Floor } \\
\text { Grid R-S, 1- } \\
2\end{array}$ & $\begin{array}{l}39 \\
\text { years }\end{array}$ & Concrete & $\begin{array}{l}\text { Spalling of } \\
\text { Concrete }\end{array}$ & $\begin{array}{l}\text { Application } \\
\text { Converter } \\
\text { Plastering }\end{array}$ & $\begin{array}{l}\text { of } \\
\text { and }\end{array}$ & $\begin{array}{r}\text { Rust } \\
\text { Epoxy }\end{array}$ \\
\hline 3 & Slab & $\begin{array}{l}\text { 2nd Floor } \\
\text { Grid V-W, } \\
10-11\end{array}$ & $\begin{array}{l}39 \\
\text { years }\end{array}$ & Concrete & $\begin{array}{l}\text { Exposed } \\
\text { Rebar }\end{array}$ & $\begin{array}{l}\text { Application } \\
\text { Converter } \\
\text { Plastering }\end{array}$ & $\begin{array}{l}\text { of } \\
\text { and }\end{array}$ & $\begin{array}{r}\text { Rust } \\
\text { Epoxy }\end{array}$ \\
\hline 4 & $\begin{array}{l}\text { Slab } \\
\text { (Canopy) }\end{array}$ & $\begin{array}{lc}\text { 2nd } & \text { Floor } \\
\text { Grid } & \text { T-W, } \\
\text { 7-8 } & \end{array}$ & $\begin{array}{l}39 \\
\text { years }\end{array}$ & Concrete & $\begin{array}{l}\text { Spalling of } \\
\text { Concrete }\end{array}$ & $\begin{array}{l}\text { Application } \\
\text { Converter } \\
\text { Plastering }\end{array}$ & $\begin{array}{l}\text { of } \\
\text { and }\end{array}$ & $\begin{array}{r}\text { Rust } \\
\text { Epoxy }\end{array}$ \\
\hline 5 & Slab & $\begin{array}{ll}\text { 2nd } & \text { Floor } \\
\text { Grid } & \text { V-W, } \\
4-5 & \end{array}$ & $\begin{array}{l}39 \\
\text { years }\end{array}$ & Concrete & $\begin{array}{l}\text { Spalling of } \\
\text { Concrete / } \\
\text { Exposed } \\
\text { Rebar }\end{array}$ & $\begin{array}{l}\text { Application } \\
\text { Converter } \\
\text { Plastering }\end{array}$ & $\begin{array}{l}\text { of } \\
\text { and }\end{array}$ & $\begin{array}{r}\text { Rust } \\
\text { Epoxy }\end{array}$ \\
\hline 6 & Slab & $\begin{array}{ll}\text { 2nd } & \text { Floor } \\
\text { Grid } & \text { W-Y, } \\
6-7 & \end{array}$ & $\begin{array}{l}39 \\
\text { years }\end{array}$ & Concrete & $\begin{array}{l}\text { Spalling of } \\
\text { Concrete / } \\
\text { Exposed } \\
\text { Rebar }\end{array}$ & $\begin{array}{l}\text { Application } \\
\text { Converter } \\
\text { Plastering }\end{array}$ & $\begin{array}{l}\text { of } \\
\text { and }\end{array}$ & $\begin{array}{r}\text { Rust } \\
\text { Epoxy }\end{array}$ \\
\hline 7 & Beam & $\begin{array}{l}\text { 2nd Floor } \\
\text { Grid V-W, } 9\end{array}$ & $\begin{array}{l}39 \\
\text { years }\end{array}$ & Concrete & $\begin{array}{l}\text { Exposed } \\
\text { Rebar }\end{array}$ & $\begin{array}{l}\text { Application } \\
\text { Converter } \\
\text { Plastering }\end{array}$ & $\begin{array}{l}\text { of } \\
\text { and }\end{array}$ & $\begin{array}{r}\text { Rust } \\
\text { Epoxy }\end{array}$ \\
\hline 8 & Beam & $\begin{array}{l}\text { 2nd Floor } \\
\text { Beam Grid } \\
\text { W, 13-14 }\end{array}$ & $\begin{array}{l}39 \\
\text { years }\end{array}$ & Concrete & $\begin{array}{l}\text { Spalling of } \\
\text { Concrete }\end{array}$ & $\begin{array}{l}\text { Application } \\
\text { Converter } \\
\text { Plastering }\end{array}$ & $\begin{array}{l}\text { of } \\
\text { and }\end{array}$ & $\begin{array}{r}\text { Rust } \\
\text { Epoxy }\end{array}$ \\
\hline 9 & Beam & $\begin{array}{l}\text { 2nd Floor } \\
\text { TV-7 }\end{array}$ & $\begin{array}{l}39 \\
\text { years }\end{array}$ & Concrete & $\begin{array}{l}\text { Spalling of } \\
\text { Concrete }\end{array}$ & $\begin{array}{l}\text { Application } \\
\text { Converter } \\
\text { Plastering }\end{array}$ & $\begin{array}{l}\text { of } \\
\text { and }\end{array}$ & $\begin{array}{r}\text { Rust } \\
\text { Epoxy }\end{array}$ \\
\hline
\end{tabular}


Global Journal of Engineering and Technology Advances, 2021, 08(03), 087-100

\begin{tabular}{|c|c|c|c|c|c|c|c|c|}
\hline 10 & Beam & $\begin{array}{l}\text { 2nd Floor } \\
\text { TV-8 }\end{array}$ & $\begin{array}{l}39 \\
\text { years }\end{array}$ & Concrete & $\begin{array}{l}\text { Spalling of } \\
\text { Concrete }\end{array}$ & $\begin{array}{l}\text { Application } \\
\text { Converter } \\
\text { Plastering }\end{array}$ & $\begin{array}{l}\text { of } \\
\text { and }\end{array}$ & $\begin{array}{r}\text { Rust } \\
\text { Epoxy }\end{array}$ \\
\hline 11 & Slab & $\begin{array}{l}\text { Roof deck } \\
\text { Grid 3-4, E- } \\
\text { F }\end{array}$ & $\begin{array}{l}39 \\
\text { years }\end{array}$ & Concrete & $\begin{array}{l}\text { Spalling of } \\
\text { Concrete / } \\
\text { Exposed } \\
\text { Rebar }\end{array}$ & $\begin{array}{l}\text { Application } \\
\text { Converter } \\
\text { Plastering }\end{array}$ & $\begin{array}{l}\text { of } \\
\text { and }\end{array}$ & $\begin{array}{r}\text { Rust } \\
\text { Epoxy }\end{array}$ \\
\hline 12 & Roof beam & Grid 4 E-F & $\begin{array}{l}39 \\
\text { years }\end{array}$ & Concrete & $\begin{array}{l}\text { Spalling of } \\
\text { Concrete / } \\
\text { Exposed } \\
\text { Rebar }\end{array}$ & $\begin{array}{l}\text { Application } \\
\text { Converter } \\
\text { Plastering }\end{array}$ & $\begin{array}{l}\text { of } \\
\text { and }\end{array}$ & $\begin{array}{r}\text { Rust } \\
\text { Epoxy }\end{array}$ \\
\hline 13 & Slab & $\begin{array}{l}\text { Roof Deck } \\
\text { Grid ST,3-4 }\end{array}$ & $\begin{array}{l}39 \\
\text { years }\end{array}$ & Concrete & $\begin{array}{l}\text { Spalling of } \\
\text { Concrete }\end{array}$ & $\begin{array}{l}\text { Application } \\
\text { Converter } \\
\text { Plastering }\end{array}$ & $\begin{array}{l}\text { of } \\
\text { and }\end{array}$ & $\begin{array}{r}\text { Rust } \\
\text { Epoxy }\end{array}$ \\
\hline 14 & Slab & $\begin{array}{l}\text { Roof Deck } \\
\text { Grid UW,3- } \\
4\end{array}$ & $\begin{array}{l}39 \\
\text { years }\end{array}$ & Concrete & $\begin{array}{l}\text { Spalling of } \\
\text { Concrete }\end{array}$ & $\begin{array}{l}\text { Application } \\
\text { Converter } \\
\text { Plastering }\end{array}$ & $\begin{array}{l}\text { of } \\
\text { and }\end{array}$ & $\begin{array}{r}\text { Rust } \\
\text { Epoxy }\end{array}$ \\
\hline
\end{tabular}

Figures shown below shows the location of tested members in Federizo Hall and its color remarks based on Description and Color Coding of Structural Members (modified from Biraris et.al, 2017).

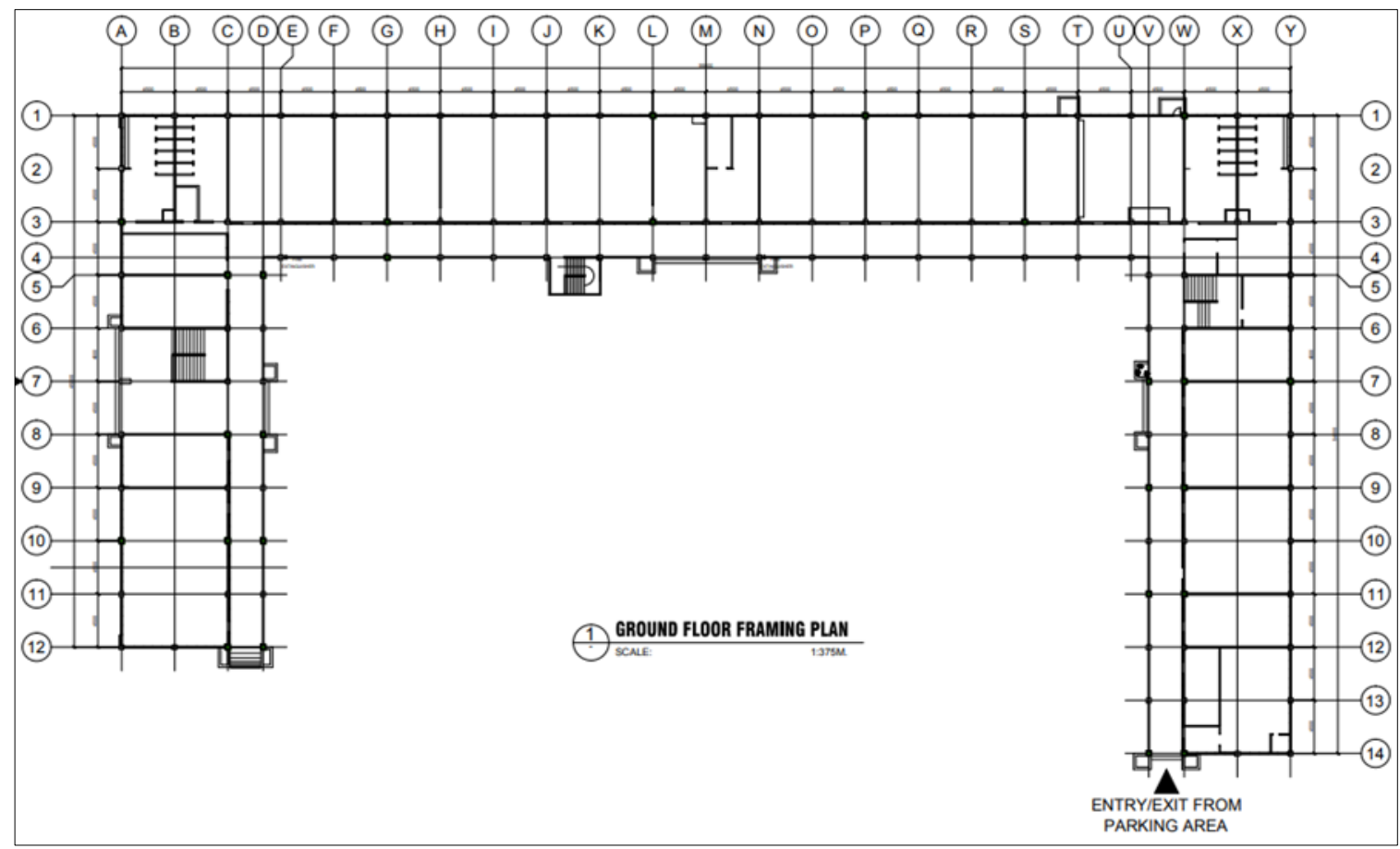

Figure 5 Color coded analysis report of Non - destructive test of Federizo Hall Ground Floor 


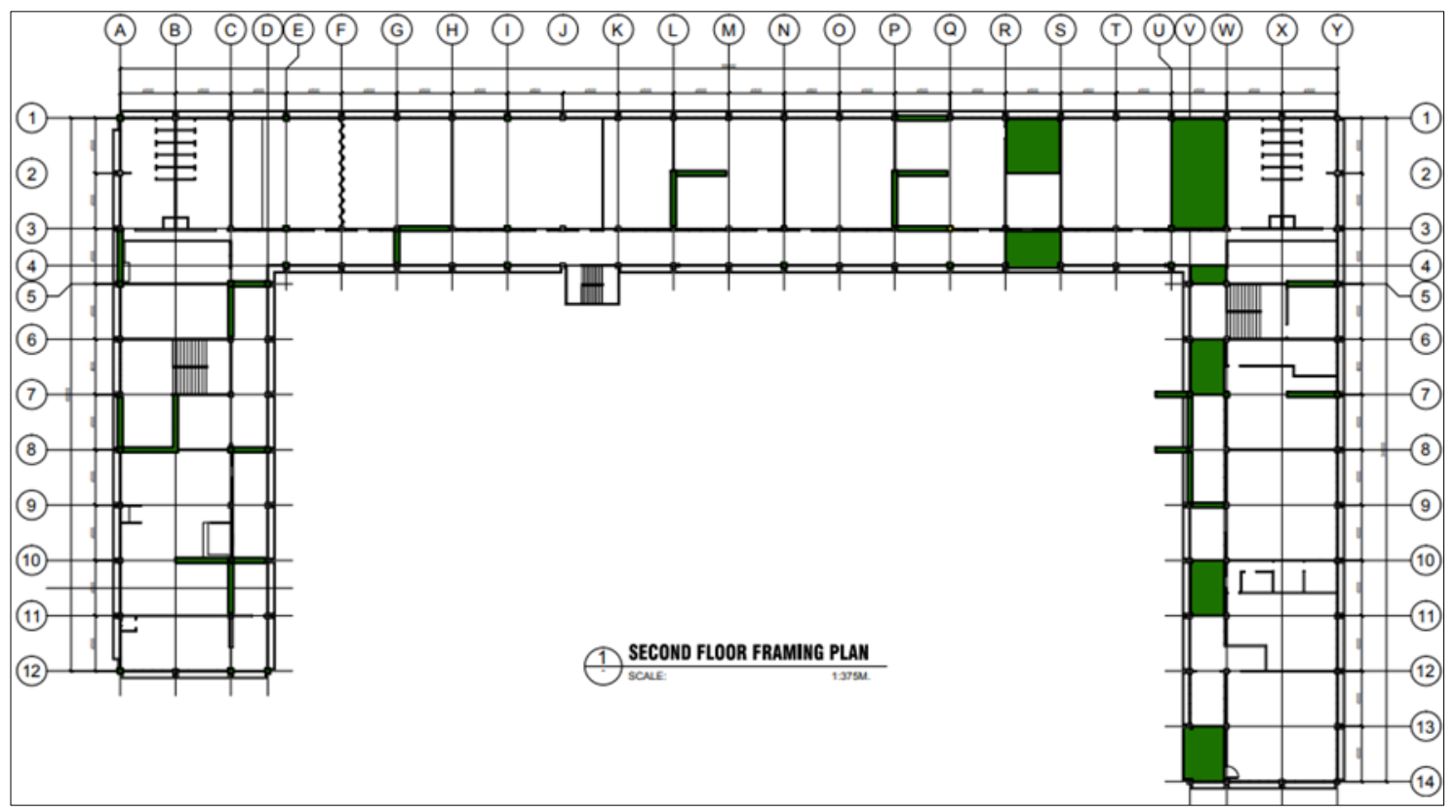

Figure 6 Color coded analysis report of Non - destructive test of Federizo Hall Second Floor

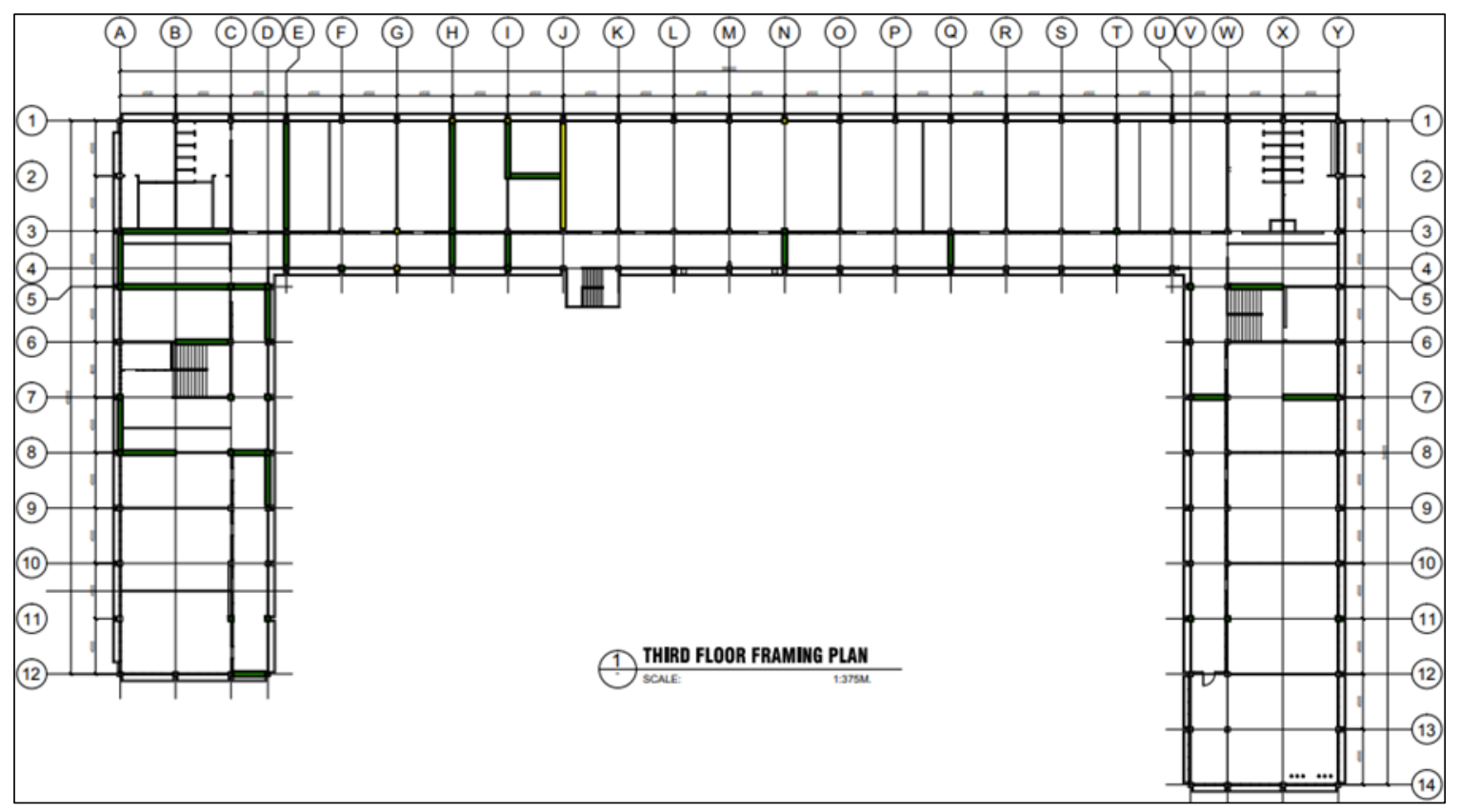

Figure 7 Color coded analysis report of Non - destructive test of Federizo Hall Third Floor 


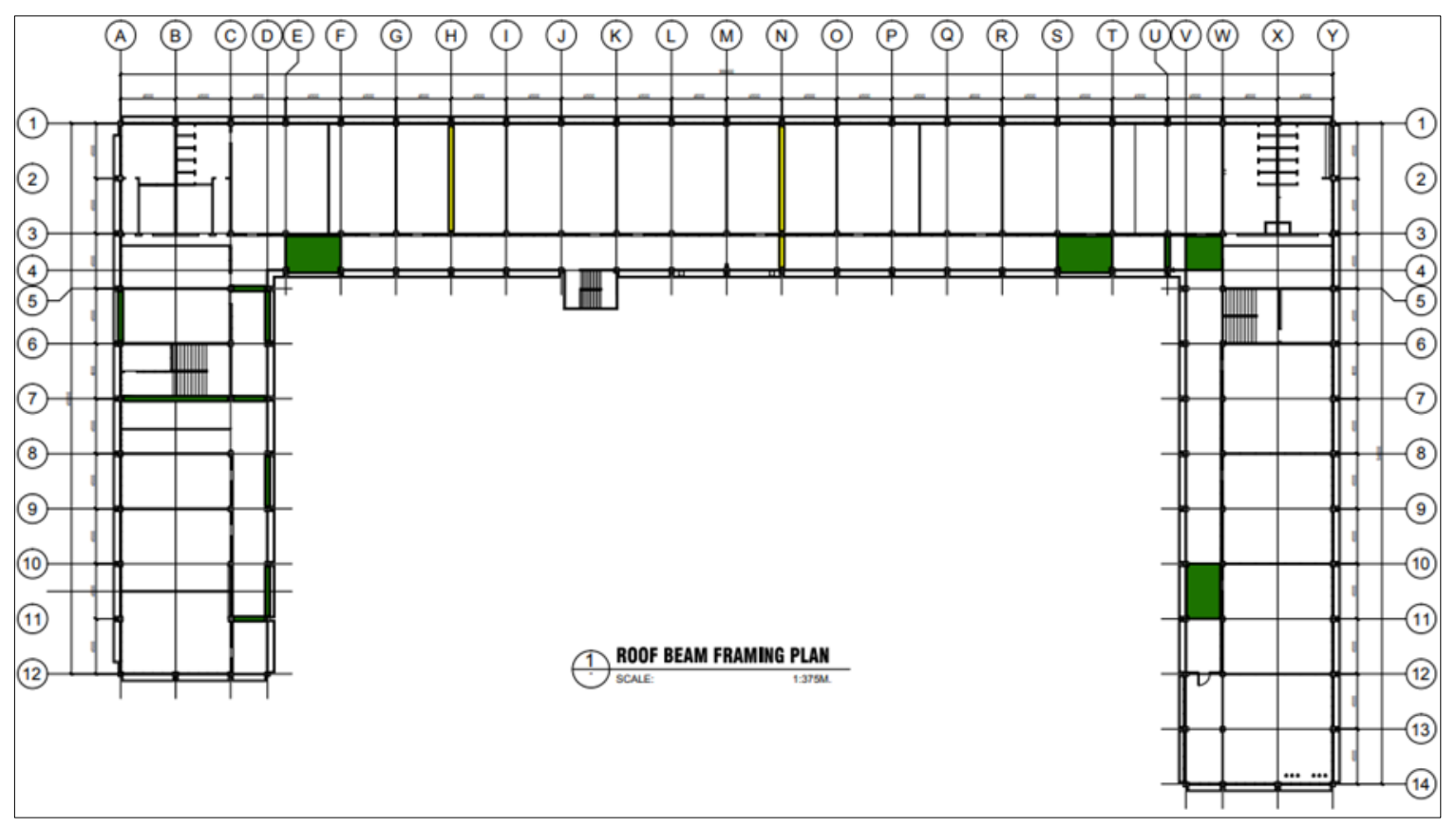

Figure 8 Color coded analysis report of Non - destructive test of Federizo Hall Roof Framing

\section{Conclusion}

Based on the findings of the study, the following conclusions were drawn.

- Some of the structural members of Carpio Hall and Federizo Hall already manifest signs of deterioration due to its age and improper maintenance. Some structural members are distress while most of it is in excellent condition. It is necessary to conduct visual/tapping observation to monitor the changes in the building and to easily determine what members are in need of repair.

- The use of non - destructive equipment like hammer rebound test is efficient in providing immediate test result and advisable to be of use as it will not contribute in the further damage of members. It is also advisable to conduct structural audit of buildings regularly or as needed to avoid more damages in the buildings.

- Structural Audit Management Plan is also necessary as it will help in providing preventive maintenance plan to increase the service life of a building.

\section{Compliance with ethical standards}

\section{Acknowledgments}

I would like to express my sincere appreciation and boundless indebtedness to all parties that was directly involved to complete this study, especially those who answer the interview. This paper will not be satisfactorily completed without their help and support.

\section{References}

[1] Biraris, Gujrathi, Dakhara, Satbhai, Vispate. Structural Audit of Old Buildings. International Journal of Engineering Trends and Technology. 2017; 43(3).

[2] MJ Monteiro, NJ Pathak. Structural Soundness of Buildings. International Journal of Earth Sciences and Engineering. ISSN 0974-5904. 2014; 04(06): 677-680.

[3] I. H. Shah. Structural Audit of Old Buildings.2008

[4] American Concrete Institute. Guide for Evaluation of Concrete Structures Prior to Rehabilitation ACI 364.1. 2019. 
[5] American Concrete Institute. Code Requirements for Evaluation, Repair and Rehabilitation of Concrete Buildings. ACI 224.1r-07.2013.

[6] Ajay Kumar BP, KN Vishwanath. Assessment of Structural Soundness and Feasibility of Additional Floor Over Existing Administration Building: Case Study. International Journal of Engineering Research \& Technology (IJERT). August - 2013; 2(8): 2278-0181.

[7] Annila, Hellemaca, Pakkala, Lahdensiva, Pentti. Extent of Moisture and Mould Damage in Structures of Public Buildings. Case Study of Construction Materials. 2017; 6: 103-108.

[8] AB Mahadik, MH Jaiswal. Structural Audit of Buildings. Research India Publications. International Journal of Civil Engineering Research. 2014; ISSN 2278-3652 5(4) 411-416.

[9] Blaine Brownell. The Age of Concrete Transmaterial: A Catalog of Materials that Redefine our Physical Environment. 2010.

[10] Gehlot, Sankhla, Gupta. Study of Concrete Quality Assessment of Structural Elements Using Rebound Hammer Test. American Journal of Engineering Research (AJER) e-ISSN: 2320-0847 p-ISSN : 2320-0936. 2016; 5(8): 192198.

[11] T Araujo, S Vieira, T Ribeiro. Analysis of Structural Integrity of a Non - Completed 28 year - old Building in the City of Patos de Minas. Journal of Building Pathology and Rehabilitation. 2016; 1(1). 